RESEARCH LETTER

\title{
Production of 2-butanol through meso-2,3-butanediol consumption in lactic acid bacteria
}

\author{
Payam Ghiaci, Francisca Lameiras, Joakim Norbeck \& Christer Larsson \\ Department of Chemical and Biological Engineering, System and Synthetic Biology, Chalmers University of Technology, Gothenburg, Sweden
}

Correspondence: Christer Larsson, Department of Chemical and Biological Engineering, System and Synthetic Biology, Chalmers University of Technology, 41296 Gothenburg, Sweden.

Tel.: +46(0)31 772 3806;

fax: +46(0)31 7723801

e-mail: christer.larsson@chalmers.se

Present address: Francisca Lameiras, Kluyverlaboratorium voor Biotechnologie, 2628 BC, Delft, The Netherlands

Received 24 June 2014; revised 13 August 2014; accepted 25 August 2014. Final version published online 22 September 2014

DOI: $10.1111 / 1574-6968.12590$

Editor: Andre Klier

Keywords

lactic acid bacteria; biofuel; microbial

biochemistry.

\section{Introduction}

The diminishing supply of fossil fuels has become a driving force for finding out new substitutes and novel chemical production paths from renewable sources. Different isomers of butanol (1-butanol, 2-butanol, iso-butanol) have been in focus as emerging biofuels among which 2butanol is known to be produced by some Lactobacilli strains (Keen et al., 1974; Radler \& Zorg, 1986; Speranza et al., 1996). 2-Butanol, compared to the other isomers, is less toxic to the cells due to its lower hydrophobicity which helps the cells to tolerate higher 2-butanol concentrations in the media (Paterson et al., 1972; Grisham \& Barnett, 1973; Hui \& Barton, 1973; Ingram, 1976).

Furthermore, 2-butanol production by Lactobacilli has been a concern of the fermented beverages industries as it might affect the taste quality of the end products (Postel, 1982). It has also been shown how 2-butanol and 2-butanone formation in Cheddar cheese is linked to different
Lactobacillus strains (Keen et al., 1974). In some Lactobacillus strains (e.g. L. brevis), 2-butanol is known to be produced through meso-2,3-butanediol which is converted to 2-butanone by a diol dehydratase enzyme. 2-butanone is then converted to 2-butanol through the action of a secondary alcohol dehydrogenase (Radler \& Zorg, 1986). The source of 2,3-butanediol is the pyruvate-diacetyl-acetoin pathway which is present in some lactic acid bacteria (Kandler, 1983) but also in a wide range of wine yeasts (Romano et al., 1998, 2000, 2003). The diol dehydratase enzyme is usually a protein of three subunits, homologs of which are produced also in Klebsiella oxytoca (Abeles et al., 1960), Salmonella typhimurium (Obradors et al., 1988), Propionibacterium (Toraya et al., 1980) and Flavobacterium (Willetts, 1979). The diol dehydratase from these bacteria is known to require adenosylcobalamin (AdoCbl) or coenzyme $\mathrm{B}_{12}$ as an essential activating component (Abeles et al., 1960; Willetts, 1979; Toraya et al., 1980; Radler \& Zorg, 1986; Obradors et al., 1988). 
The very last enzyme of 2-butanol conversion in Lactobacillus strains, secondary alcohol dehydrogenase, is attractive due to its capacity for reducing ketones to the relevant alcohols enantioselectively, which makes it a promising biocatalyst (Leuchs \& Greinera, 2011). The rising demand for pure enantiomer intermediates in pharmaceutical industries has also been a driving factor in this regard (Meyer, 2010). The secondary alcohol dehydrogenase from Lactobacillus brevis ( $L b S A D H)$, in particular, shows affinity for an extensive range of substrates and it is also known to be solvent tolerant (Leuchs \& Greinera, 2011).

In this study, a range of lactic acid bacteria were screened for 2-butanol production capability and the kinetic properties of the relevant enzymes were assessed for the two best 2-butanol producers.

\section{Materials and methods}

\section{Strains}

The Lactobacillus brevis strains SE20 and SE31 together with 16 isolates of L. plantarum, eight isolates of L. pantheris, two isolates of $L$. buchneri, two isolates of $L$. rossiae and one isolate of L. paracasei, L. fermentum and L. paracollinoids were isolated from the ethanol pilot plant facility in Örnsköldsvik, Sweden. The strain L. brevis (LB 734, Centre National de Recherches Zootechniques - CNRZ 734) was kindly provided by Professor Giovanna Speranza, Department of Organic and Industrial Chemistry, University of Milan, Italy. Lactobacillus brevis strains LB 215, LB 219, LB 350, LB 368, LB 399, LB 443, LB 579 and one isolate of $L$. malefermentas were obtained from the Culture Collection, University of Gothenburg (CCUG).

\section{Cultivation conditions}

MRS (OXOID, UK) and SM2 medium were used to cultivate the strains. MRS medium was composed of peptone $10 \mathrm{~g} \mathrm{~L}^{-1}$, 'Lab-Lemco' $8 \mathrm{~g} \mathrm{~L}^{-1}$, yeast extract $4 \mathrm{~g} \mathrm{~L}^{-1}$, glucose $20 \mathrm{~g} \mathrm{~L}^{-1}$, 'Tween 80' $1 \mathrm{~mL}$, di-potassium hydrogen phosphate $2 \mathrm{~g} \mathrm{~L}^{-1}$, sodium acetate. $3 \mathrm{H}_{2} \mathrm{O} 5 \mathrm{~g} \mathrm{~L}^{-1}$, triammonium citrate $2 \mathrm{~g} \mathrm{~L}^{-1}$, magnesium sulfate. $7 \mathrm{H}_{2} \mathrm{O}$ $0.2 \mathrm{~g} \mathrm{~L}^{-1}$, manganese sulfate. $4 \mathrm{H}_{2} \mathrm{O} 0.05 \mathrm{~g} \mathrm{~L}^{-1}$. SM2 medium was prepared according to Radler and Zorg (Radler \& Zorg, 1986). The cells were grown in 50-mL Falcon tubes at 150 r.p.m. in $30^{\circ} \mathrm{C}$.

\section{Enzyme extraction}

Enzyme extraction was performed following the procedure of Schütz \& Radler (1984), with some minor modifications. Cells were cultivated in SM2 medium for $48 \mathrm{~h}$ and harvested at $1500 \mathrm{~g}$ for $10 \mathrm{~min}$. The cells were then washed twice in $10 \mathrm{mM}$ potassium phosphate ( $\mathrm{pH}$ 7.2) and $1 \mathrm{mM}$ dithiothreitol buffer. Finally, cells were suspended in $2 \mathrm{~mL}$ of the same buffer. The suspension was transferred to lysing matrix E (MРтM) tubes. Fastprep 24 (MP Biomedicals Solon) was used to disrupt the cells (five cycles of $20 \mathrm{~s}$ at $6 \mathrm{~m} \mathrm{~s}^{-1}$, kept on ice for $1 \mathrm{~min}$ in between each cycle). Cell debris was then removed by centrifuging at $14000 \mathrm{~g}$ for $30 \mathrm{~min}\left(4^{\circ} \mathrm{C}\right)$. Samples were desalinated by use of a spinning column: amicon ultracel-4 10k device (Merk Millipore).

\section{Total protein concentration}

The protein concentration was determined using Nanodrop2000 spectrophotometer (Termo Scientific). Absorbance was measured at $280 \mathrm{~nm}$, and concentration was calculated following the Beer's law.

\section{Enzyme activity measurements}

Secondary alcohol dehydrogenase - Enzyme assay was performed following Jo et al. (Jo et al., 2008). A total volume of $1 \mathrm{~mL}$ including potassium phosphate buffer pH 7 (final concentration of $50 \mathrm{mM}$ ), dithiothreitol (final concentration of $10 \mathrm{mM}$ ), $0.5-100 \mathrm{mM}$ substrate (2-butanol, 1-propanol, ethanol, or 2-butanone), $\mathrm{NAD}^{+} /$ $\mathrm{NADH}$ (final concentration of $2 \mathrm{mM} / 1 \mathrm{mM}$ respectively), and crude extract was prepared. For the reducing reaction, 2-butanone was used as substrate and $\mathrm{NADH}$ as coenzyme. 2-butanol, 1-propanol, or ethanol was used as substrate for oxidation reaction, together with $\mathrm{NAD}^{+}$ as coenzyme.

The activity of alcohol dehydrogenase was determined by measuring the reduction/oxidation of $\mathrm{NAD}^{+} / \mathrm{NADH}$ at $340 \mathrm{~nm}$ using a plate reader (Fluostar Omega, BMG LabTech) at $30{ }^{\circ} \mathrm{C}$.

Diol dehydratase - This assay was performed following Toraya et al. (1977). A mixture of $0.05 \mathrm{M}$ potassium chloride, $0.035 \mathrm{M}$ potassium phosphate buffer $\mathrm{pH}$ $8,15 \mu \mathrm{M}$ adenosylcobalamin, $0.05 \mathrm{M}$ substrate $(1,2-$ propanediol, 1,3-propanediol, meso-2,3-butanediol, glycerol), and enzyme crude extract was incubated at $37{ }^{\circ} \mathrm{C}$ for $10 \mathrm{~min}$. Then, $0.5 \mathrm{~mL} 0.1 \mathrm{M}$ potassium citrate buffer $(\mathrm{pH}$ 3.6) was added to terminate the reaction followed by $0.25 \mathrm{~mL} \quad 0.1 \%$ MBTH hydrochloride. The aldehydes/ketones produced have the ability to react with MBTH, forming azine derivates which can be determined by spectrophotometer (Paz et al., 1965). The mixture was then incubated at $37^{\circ} \mathrm{C}$, and $0.5 \mathrm{~mL}$ water was added before measuring its absorbance at 
$305 \mathrm{~nm}$ in plate reader (Fluostar Omega, BMG LabTech).

\section{Analysis of extracellular metabolites}

HPLC (Ultimate 3000, Dionex) was used to analyze metabolites such as glucose, ethanol, glycerol, acetate, meso-2,3-butanediol, 2-butanone, and 2-butanol. Aminex ${ }^{\circledR}$ HPX- $87 \mathrm{H}$ column $(300 \times 7.8 \mathrm{~mm}-$ Bio-Rad $)$ was used, and $5 \mathrm{mM} \quad \mathrm{H}_{2} \mathrm{SO}_{4}$ was the eluent (at $\left.0.6 \mathrm{~mL} \mathrm{~min}{ }^{-1}\right)$. The running temperature was $45^{\circ} \mathrm{C}$. VWD-3100 detector (Thermo Scientific Dionex) was connected to the column, and each metabolite was quantified based on a standard curve drawn for each metabolite. The concentration range of standards was as follow: acetate $\left(0.1-2 \mathrm{~g} \mathrm{~L}^{-1}\right)$, glycerol $\left(0.1-2 \mathrm{~g} \mathrm{~L}^{-1}\right)$, ethanol $\left(1-15 \mathrm{~g} \mathrm{~L}^{-1}\right)$, glucose $\left(1-20 \mathrm{~g} \mathrm{~L}^{-1}\right)$, 2-butanol and butanone $\left(0.1-2 \mathrm{~g} \mathrm{~L}^{-1}\right)$, meso-2,3-butanediol $\left(0.5-5 \mathrm{~g} \mathrm{~L}^{-1}\right)$. Rezextm ROA - organic acid $\mathrm{H}^{+}(300 \times 7.8 \mathrm{~mm}-$ Phenomenex) was the second column used to reconfirm the methanol peak in the medium. $5 \mathrm{mM} \mathrm{H}_{2} \mathrm{SO}_{4}$ was the eluent (at $0.8 \mathrm{~mL} \mathrm{~min}^{-1}$ ), and the running temperature was $80{ }^{\circ} \mathrm{C}$.

\section{Results and discussion}

\section{2-Butanol production}

As an initial screen, we tested the ability of 42 different isolates of lactic acid bacteria for their ability to consume meso-2,3-butanediol. The following species were included in this first screen, L. plantarum (16 isolates), L. brevis (10 isolates), L. pantheris (eight isolates), L. buchneri (two isolates), L. rossiae (two isolates) and L. paracasei, L. fermentum, L. paracollinoids, L. malefermentas (one isolate each). Among these the only species that showed any capacity for meso-2,3-butanediol consumption were L. brevis and L. buchneri (data not shown). It was therefore decided to include only these two species in the next step of investigations. Ten strains of L. brevis and two strains of L. buchneri were screened for their 2-butanol production capability during growth in MRS medium with addition of either meso.2,3-butanediol or butanone (Table 1). The origin of these strains were ethanol pilot plant (Albers et al., 2011), fermenting olives (CCUG 21531), wine (CCUG 21959), industrial fermentation process (CCUG 35039), carrot (CCUG 39980), cider (CCUG 44317), silage (CCUG 36840), pickles (CCUG 57950), and French cheese (CNRZ 734, previously reported as a 2-butanol producer from meso-2,3-butanediol). All the tested strains were capable of consuming meso-2,3-butanediol and converting 2-butanone to 2-butanol, while grown in MRS medium (Table 1). However, none of them showed any production of 2-butanol from meso2,3-butanediol.Instead, a clear peak of methanol was identified in the HPLC spectrum. Therefore, we assume provision of meso-2,3-butanediol in MRS medium led to methanol production by the tested LB strains.

The fact that even the previously reported butanol producing strain (LB 734) failed to show any butanediol-buta-

Table 1. List of different Lactobacillus brevis and L. buchneri strains tested for production of 2-butanol during growth in MRS medium with addition of meso-2,3-butanediol $\left(5 \mathrm{~g} \mathrm{~L}^{-1}\right)$ or 2-butanone $\left(0.8 \mathrm{~g} \mathrm{~L}^{-1}\right)$

\begin{tabular}{|c|c|c|c|c|}
\hline Strain & Source & $\begin{array}{l}\text { meso-2,3-butanediol } \\
\text { consumption }\end{array}$ & $\begin{array}{l}\text { 2-butanol from } \\
\text { meso-2,3-butanediol }\end{array}$ & $\begin{array}{l}\text { 2-butanol from } \\
\text { butanone }\left(\mathrm{g} \mathrm{L}^{-1}\right)\end{array}$ \\
\hline \multicolumn{5}{|c|}{ L. buchneri } \\
\hline LB 12 & $\begin{array}{l}\text { Ethanol pilot plant, } \\
\text { Örnsköldsvik }\end{array}$ & Yes & No & 0.04 \\
\hline LB 16 & $\begin{array}{l}\text { Ethanol pilot plant, } \\
\text { Örnsköldsvik }\end{array}$ & Yes & No & 0.03 \\
\hline \multicolumn{5}{|l|}{ L. brevis } \\
\hline SE 20 & $\begin{array}{l}\text { Ethanol pilot plant, } \\
\text { Örnsköldsvik }\end{array}$ & Yes & No & 0.44 \\
\hline SE 31 & $\begin{array}{l}\text { Ethanol pilot plant, } \\
\text { Örnsköldsvik }\end{array}$ & Yes & No & 0.59 \\
\hline LB 215 & CCUG 21531 & Yes & No & 0.72 \\
\hline LB 219 & CCUG 21959 & Yes & No & 0.68 \\
\hline LB 350 & CCUG 35039 & Yes & No & 0.16 \\
\hline LB 368 & CCUG 36840 & Yes & No & 0.59 \\
\hline LB 399 & CCUG 39980 & Yes & No & 0.49 \\
\hline LB 443 & CCUG 44317 & Yes & No & 0.55 \\
\hline LB 579 & CCUG 57950 & Yes & No & 0.66 \\
\hline LB 734 & CNRZ 734 & Yes & No & ND \\
\hline
\end{tabular}

ND, not determined. 
Butanone-Butanol conversion in SM2 medium

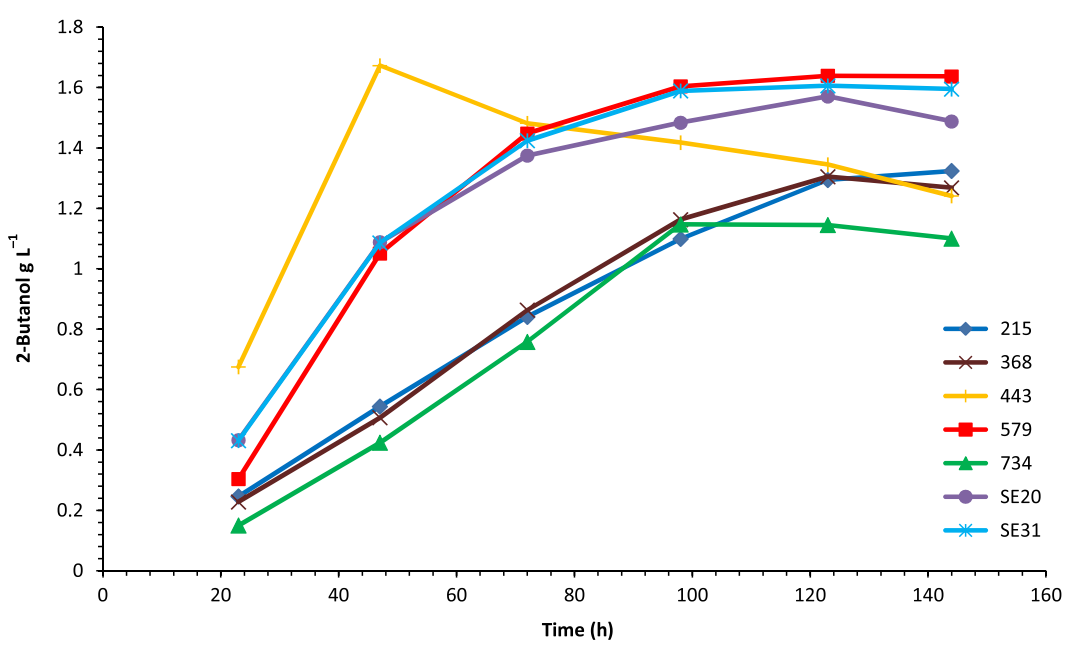

Fig. 1. Conversion of 2-butanone to 2-butanol by different Lactobacillus brevis strains grown in SM2 medium. SE31 (asterisk), SE20 (filled circle), LB 579 (filled square), LB 215 (filled diamond), LB 734 (filled triangle), LB 368 (cross), and LB 443 (plus). Cells were cultivated in SM2 medium with addition of $0.8 \mathrm{~g} \mathrm{~L}^{-1}$ butanone.

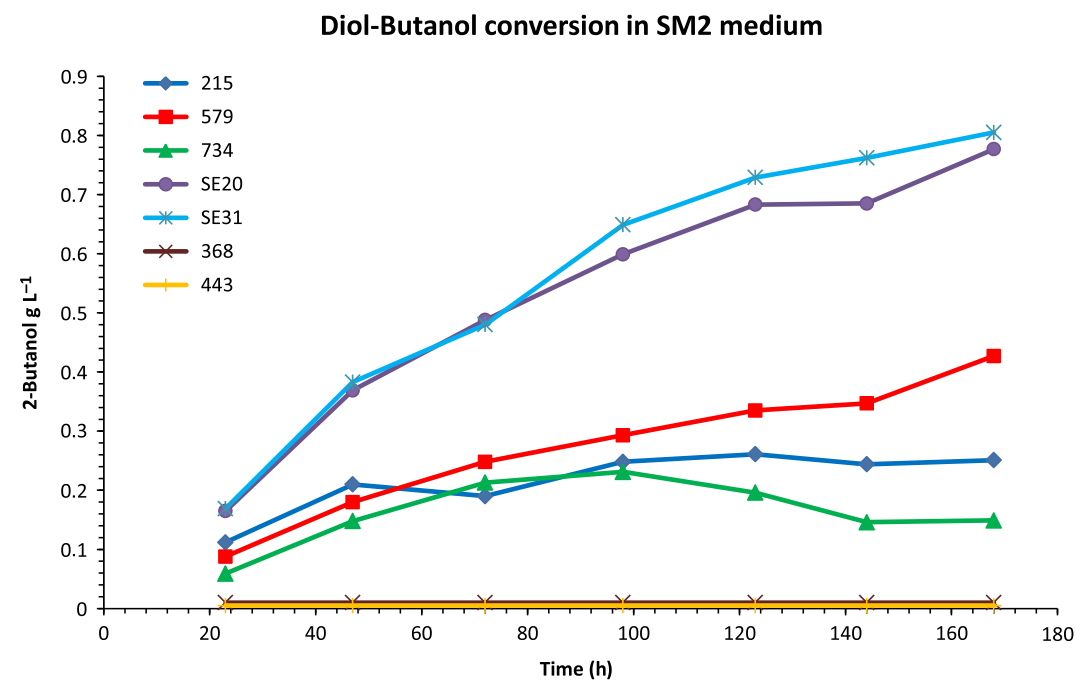

Fig. 2. Conversion of meso-2,3-butanediol to 2-butanol by different Lactobacillus brevis strains grown in SM2 medium. SE31 (asterisk), SE20 (filled circle), LB 579 (filled square), LB 215 (filled diamond), and LB 734 (filled triangle). Cells were cultivated in SM2 medium with addition of $3 \mathrm{~g} \mathrm{~L}^{-1}$ meso-2,3-butanediol.

nol conversion capability, made us hypothesize that a rich complex media such as MRS cause repression of genes required for conversion of 2,3-butanediol to butanol. Therefore, six of the L. brevis strains showing the highest meso-2,3-butanediol consumption rate together with LB 734 (previously reported as 2-butanol producer) were tested for their ability to produce 2-butanol from butanone and meso-2,3-butanediol in a synthetic medium (SM2). As expected all the tested strains could convert butanone to 2-butanol also in this media (Fig. 1), and the final concentration was higher compared to growth in MRS (Table 1, Fig. 1). Furthermore, five strains of seven could also convert meso-2,3-butanediol to 2-butanol in this medium (Fig. 2). The isolates, SE20 and SE31, were found to be the best 2-butanol producers with about $0.8 \mathrm{~g} \mathrm{~L}^{-1}$ 2-butanol produced after 7 days (equivalent to conversion yield of $0.8 \mathrm{~g} \mathrm{~g}^{-1}$ of 2,3-butanediol), while the strain reported to show the highest production in a previous study (Speranza 
Table 2. Secondary alcohol dehydrogenase kinetics for SE2O and SE31 in both reducing and oxidizing directions

\begin{tabular}{|c|c|c|c|c|}
\hline & \multicolumn{2}{|c|}{ 2-butanone $+\mathrm{NADH} \rightarrow$ 2-butanol $+\mathrm{NAD}^{+}$} & \multicolumn{2}{|c|}{ 2-butanol $+\mathrm{NAD}^{+} \rightarrow$ 2-butanone $+\mathrm{NADH}$} \\
\hline & $K_{\mathrm{m}}(\mathrm{mM})$ & $V_{\max }\left(\mu \mathrm{mol} \min ^{-1} \mathrm{~g}^{-1}\right)$ & $K_{\mathrm{m}}(\mathrm{mM})$ & $V_{\max }\left(\mu \mathrm{mol} \min ^{-1} \mathrm{~g}^{-1}\right)$ \\
\hline SE 20 & $0.22 \pm 0.65$ & $1.60 \pm 0.26$ & $1.26 \pm 0.82$ & $2.50 \pm 0.32$ \\
\hline SE 31 & $0.51 \pm 0.08$ & $7.90 \pm 0.30$ & $1.36 \pm 0.36$ & $10.0 \pm 0.55$ \\
\hline
\end{tabular}

Table 3. Specific activity of SE20 diol dehydratase toward different substrates. Cells were cultivated in SM2 medium without or with addition of 1,2-propanediol or 2,3-butanediol

\begin{tabular}{|c|c|c|c|c|}
\hline \multirow[b]{2}{*}{ Grown in } & \multicolumn{4}{|c|}{ Specific activity $\left(\mu \mathrm{mol} \min ^{-1} \mathrm{~g}^{-1}\right)$} \\
\hline & 1,2-propanediol & 2,3-butanediol & Glycerol & 1,3-propanediol \\
\hline SM2 & $<0.1$ & $<0.1$ & $<0.1$ & $<0.1$ \\
\hline SM2 + 1,2-propanediol & $0.19 \pm 0.001$ & $0.08 \pm 0.001$ & $0.10 \pm 0.001$ & $0.11 \pm 0.001$ \\
\hline $\mathrm{SM} 2+$ 2,3-butanediol & $0.13 \pm 0.001$ & $0.10 \pm 0.002$ & $0.22 \pm 0.001$ & $0.16 \pm 0.001$ \\
\hline
\end{tabular}

et al., 1996), LB 734, produced $0.29 \mathrm{~g} \mathrm{~L}^{-1}$. Major part of growth occurred within the first $24 \mathrm{~h}$ while butanol production continued for up to 7 days.

\section{Enzyme kinetics}

The two best producers of 2-butanol, SE20 and SE31, were chosen for characterization of their secondary alcohol dehydrogenase and diol dehydratase kinetics.

The kinetics of the secondary alcohol dehydrogenases were measured in both reduction and oxidation directions (2-butanone $+\mathrm{NADH} \rightarrow$ 2-butanol $+\mathrm{NAD}^{+}$). Eadie-Hofstee plot was used to calculate $K_{\mathrm{m}}$ and $V_{\max }$ values which are shown in Table 2. SE31 shows an about fourfold higher $V_{\max }$ value for both reduction and oxidization reactions compared to SE20 while $K_{\mathrm{m}}$ values were not significantly different for the two strains. Furthermore, the $V_{\max }$ values for butanone reduction or butanol oxidation were not very different, but the $K_{\mathrm{m}}$ for butanol seemed to be higher than for butanone (Table 2).

Concerning the diol dehydratase, it was not possible to make a proper kinetic characterization of this enzyme. The activity at saturated substrate concentrations $(0.05 \mathrm{M})$ was measured (Table 3$)$. We could observe that the expression, as judged from the activity of the enzyme, was induced in the presence of its substrate in the growth medium. This could be due to either transcriptional or post-transcriptional processes. When cells were grown in the presence of 1,2-propanediol or 2,3-butanediol, the extracted diol dehydratase showed activity toward a range of substrates; 1,2-propanediol, meso-2,3-butanediol, 1,3-propanediol and glycerol (Table 3 ). The highest activity for 1,2-propanediol and 2,3-butanediol, respectively, was recorded when the same substrate was present in the medium during cultivation (Table 3 ). No diol dehydratase activity was observed when cells were grown in SM2 without any substrate added. This is consistent with the findings of Ailion \& Roth (1997) which showed that in Salmonella, the presence of 1,2-propanediol induced transcription of expression from the pdu and cob operons encoding the propanediol dehydratase and adenosylcobalamin biosynthesis genes, respectively.

The ability to produce 2-butanol from 2,3-butanediol seems to be widespread among L. brevis strains. However, the conversion process seems to be repressed during optimal growth conditions in rich laboratory media. Furthermore, the presence of proper substrate is a prerequisite for induction of the diol dehydratase. Hence, this enzyme is regulated both via a repression and an induction mechanism.

\section{Acknowledgements}

We gratefully acknowledge Swedish Energy Agency (project no. 32918-1) and Chalmers Energy Area of Advance, whose funding made this project possible. We are also thankful to Professor Giovanna Speranza, Department of Organic and Industrial Chemistry, University of Milan, Italy, for providing the strain LB734. We thank Karl Persson for providing the graphical abstract.

\section{References}

Abeles RH, Brownstein AM \& Randles CH (1960) beta-Hydroxypropionaldehyde, an intermediate in the formation of 1,3-propanediol by Aerobacter aerogenes. Biochim Biophys Acta 41: 530-531.

Ailion M \& Roth JR (1997) Repression of the cob operon of Salmonella typhimurium by adenosylcobalamin is influenced by mutations in the pdu operon. J Bacteriol 179: 6084-6091.

Albers E, Johansson E, Franzen CJ \& Larsson C (2011) Selective suppression of bacterial contaminants by process conditions during lignocellulose based yeast fermentations. Biotechnol Biofuels 4: 59.

Grisham CM \& Barnett RE (1973) The effects of long-chain alcohols on membrane lipids and the $(\mathrm{Na}++\mathrm{K}+)$-ATPase. Biochim Biophys Acta 311: 417-422. 
Hui FK \& Barton PG (1973) Mesomorphic behaviour of some phospholipids with aliphatic alcohols and other non-ionic substances. Biochim Biophys Acta 296: 510-517.

Ingram LO (1976) Adaptation of membrane lipids to alcohols. J Bacteriol 125: 670-678.

Jo JE, Mohan Raj S, Rathnasingh C, Selvakumar E, Jung WC \& Park S (2008) Cloning, expression, and characterization of an aldehyde dehydrogenase from Escherichia coli K-12 that utilizes 3-Hydroxypropionaldehyde as a substrate. Appl Microbiol Biotechnol 81: 51-60.

Kandler O (1983) Carbohydrate metabolism in lactic acid bacteria. Antonie Van Leeuwenhoek 49: 209-224.

Keen AR, Walker NJ \& Peberdy MF (1974) The formation of 2-butanone and 2-butanol in Cheddar cheese. J Dairy Res 41: 249-257.

Leuchs S \& Greinera L (2011) Alcohol dehydrogenase from Lactobacillus brevis: a versatile robust catalyst for enantioselective transformations. Chem Biochem Eng Q 25: 267-281.

Meyer H-P (2010) Sustainability and biotechnology. Org Process Res Dev 15: 180-188.

Obradors N, Badia J, Baldoma L \& Aguilar J (1988) Anaerobic metabolism of the L-rhamnose fermentation product 1,2-propanediol in Salmonella typhimurium. J Bacteriol 170: 2159-2162.

Paterson SJ, Butler KW, Huang P, Labelle J, Smith IC \& Schneider H (1972) The effects of alcohols on lipid bilayers: a spin label study. Biochim Biophys Acta 266: 597-602.

Paz MA, Blumenfeld OO, Rojkind M, Henson E, Furfine C \& Gallop PM (1965) Determination of carbonyl compounds with N-methyl benzothiazolone hydrazone. Arch Biochem Biophys 109: 548-559.

Postel W (1982) Butanol-(2) as an evaluation criterion in wine, wines for distillation, and wine distillates. Deut Lebensm-Rundsch 78: 211-215.
Radler F \& Zorg J (1986) Characterization of the enzyme involved in formation of 2-butanol from meso-2,3-butanediol by lactic acid bacteria. Am J Enol Vitic 37: 206-210.

Romano P, Brandolini V, Ansaloni C \& Menziani E (1998) The production of 2,3-butanediol as a differentiating character in wine yeasts. World J Microbiol Biotechnol 14: 649-653.

Romano P, Palla G, Caligiani A, Brandolini V, Maietti A \& Salzano G (2000) Evaluation of stereoisomers of 2,3-butanediol and acetoin to differentiate Saccharomyces cerevisiae and Kloeckera apiculata wine strains. Biotechnol Lett 22: 1947-1951.

Romano P, Fiore C, Paraggio M, Caruso M \& Capece A (2003) Function of yeast species and strains in wine flavour. Int J Food Microbiol 86: 169-180.

Schütz H \& Radler F (1984) Anaerobic reduction of glycerol to propanediol-1.3 by Lactobacillus brevis and Lactobacillus buchneri. Syst Appl Microbiol 5: 169-178.

Speranza G, Manitto P, Fontana G, Monti D \& Galli A (1996) Evidence for enantiomorphic-enantiotopic group discrimination in diol dehydratase-catalyzed dehydration of meso-2,3-butanediol. Tetrahedron Lett 37: 4247-4250.

Toraya T, Ushio K, Fukui S \& Hogenkamp PC (1977) Studies on the mechanism of the adenosylcobalamin-dependent diol dehydrase reaction by the use of analogs of the coenzyme. $J$ Biol Chem 252: 963-970.

Toraya T, Kuno S \& Fukui S (1980) Distribution of coenzyme B12-dependent diol dehydratase and glycerol dehydratase in selected genera of Enterobacteriaceae and Propionibacteriaceae. J Bacteriol 141: 1439-1442.

Willetts A (1979) Bacterial metabolism of propane-1,2-diol. Biochim Biophys Acta 588: 302-309. 